\title{
An investigation of risk factors for two successive cases of clinical mastitis in the same lactation
}

\author{
J.C.F. Pantoja*, A.P. Almeida, B. dos Santos, R.S. Rossi \\ Department of Veterinary Hygiene and Public Health, UNESP - Univ Estadual Paulista, Distrito de Rubiao Junior S/N, Botucatu, Sao Paulo 18618-970, \\ Brazil
}

\section{A R T I C L E I N F O}

\section{Keywords:}

Clinical mastitis

Milk quality

Epidemiology

Dairy cows

Teat-end hyperkeratosis

Milking ease

\begin{abstract}
A B S T R A C T
The objective of this study was to identify risk factors for the occurrence of two successive cases of clinical mastitis (CM). Two farms were visited monthly during 10 months. Milk samples were collected from all cases of $\mathrm{CM}$ that occurred during the study. Cows were observed prospectively from the beginning of the study and a case cow was defined when she experienced the second case of $\mathrm{CM}$ within the same lactation. For each case cow, 3 control cows matched by days in milk (DIM) were randomly selected from the cohort of cows who did not experience CM. On each visit day, a series of udder and teat characteristics were recorded during milking time: teat-end hyperkeratosis scoring, milking ease scoring, teat length and diameter, teat-to-ground distance, and udder position in relation to the hock. A total of 113 case cows and 324 control cows were used for analyses. The median time to occurrence of the first case of CM was 84 DIM and the median interval between the first and second cases of $\mathrm{CM}$ was 39 days. Of all second cases, $49.6 \%(\mathrm{~N}=55)$ occurred in the same mammary gland. Of these 55 cases, $29.1 \%$ had identical milk culture results from both first and second cases. Most cases of CM were caused by coliforms and environmental streptococci. Teat-to-ground distance, teat-end hyperkeratosis, udder position in relation to the hock, milking ease, parity, and milk production at the first test of lactation were individually associated with the occurrence of two successive cases of CM. Of all explanatory variables, 3 remained in the final multivariable model. The odds of two successive cases of CM were 3.7 times greater for cows who were "very easy to milk", as compared with cows who were "difficult to milk". Cows who had their udders below the hock, and those of parity > 2 were 3.6 and 2.5 times more likely to experience two successive cases of CM, as compared with cows whose udder was positioned above the hock, and cows of parity 1 , respectively. Findings of this study highlight the importance of teat and udder characteristics as risk factors for two successive cases of CM. Further investigations are needed to elucidate the role of the teat canal in preventing mastitis for modern cows that have been selected for increased milk production, shorter teats, and greater milk flow rates.
\end{abstract}

\section{Introduction}

Control of clinical mastitis (CM) is increasingly challenging on farms that produce high-quality milk worldwide. Results of studies conducted in developed dairy regions and including large populations of herds indicate that $20.1-40 \%$ of dairy cows experience CM every year (Barnouin et al., 2005; Bradley et al., 2007; Olde Riekerink et al., 2008). The cost of a single case has been estimated between $€ \$ 210$ and $€ \$ 287$ (Halasa et al., 2007; Huijps et al., 2008), resulting in great economic losses to producers.

Changes in mastitis etiology, genetic selection of cows, and management practices are factors that have contributed to increasing the burden of CM on modern dairy herds. Environmental pathogens such as coliforms, which are primarily associated with $\mathrm{CM}$, have become more prevalent due to successful control and eradication of contagious pathogens (Lago et al., 2011; Oliveira and Ruegg, 2014). Cows have also been intensively selected to increase milk production and milking speed (i.e., milk flow rate), with the former being consistently correlated with increased susceptibility to CM (Rupp and Boichard, 2003). Moreover, maintenance of teat health has been challenging on large dairy operations due to increasing exposure to management practices used towards maximizing milk production (e.g., 3-times-aday milking) and minimizing milking time (e.g., milking machines settings).

In this context, identification of risk factors is needed to prevent and manage $\mathrm{CM}$ at the farm level. Several cow factors have been

\footnotetext{
* Corresponding author.

E-mail address: pantoja@fmvz.unesp.br (J.C.F. Pantoja).
} 
associated with the occurrence of CM, among which are parity (Breen et al., 2009; Hertl et al., 2014), milk production (Hertl et al., 2014), stage of lactation (Olde Riekerink et al., 2008; Breen et al., 2009), somatic cell count (SCC) previous to CM (Green et al., 2004; Steeneveld et al., 2008), breed (Barkema et al., 1999), and teat pathologies and anatomical characteristics (Grindal and Hillerton, 1991; Neijenhuis et al., 2001; Breen et al., 2009).

It has also been consistently demonstrated that cows that experience CM are more likely to develop further cases in both current and subsequent lactations (Bar et al., 2007; Steeneveld et al., 2008; Pantoja et al., 2009; Hertl et al., 2014). Cows who experience repeated cases of $\mathrm{CM}$ are a relevant issue for dairy producers because there is frustration due to repeated treatment failures and cumulative economic losses throughout lactation. Pinzón-Sánchez and Ruegg (2011) reported that the overall bacteriological cure rate after intramammary treatment with ceftiofur was less (51.9\%) for cows who experienced previous cases of $\mathrm{CM}$, than that observed for cows who did not experience any previous case in the same lactation (86.5\%).

Milk production losses accumulate with the number of additional cases of $\mathrm{CM}$ in the same lactation. As compared to the projected lactational milk yield of healthy cows, average reductions were of 253, 238 and $216 \mathrm{~kg}$ within 60 days after cows developed the first, second and third case of CM in lactation, respectively (Bar et al., 2007). The pattern of milk loss also depends on parity, causative agent, and similarity of the pathogens causing subsequent episodes of CM (Hertl et al., 2014). Moreover, cows who experience repeated cases of CM are at greater risk of dying or being prematurely culled from the herd (Bar et al., 2008).

It is well defined that chronic intramammary infections, which can alternate between subclinical and clinical states, and treatment failures are causes of repeated episodes of CM (Bradley and Green, 2001; Hillerton and Kliem, 2002). Nonetheless, on modern farms, in which the distribution of pathogens is mostly comprised of environmental organisms, most repeated cases of CM are caused by different species of pathogens, or different strains of the same species (Abureema et al., 2014), suggesting that cow factors unrelated to pathogens play a major role in increasing the susceptibility to repeated episodes of CM.

The objective of this study was to identify risk factors for the occurrence of two successive cases of CM in the same lactation, with a focus on udder and teat physical characteristics that could be managed at the farm level, or by means of genetic selection.

\section{Methods}

This research was approved by the UNESP's Ethics Committee for Animal Use (protocol 156/2013).

\subsection{Farm selection and herd characteristics}

A convenience sample of 2 dairy farms was selected for the study. Herds were eligible to participate if located in Sao Paulo State, Brazil, were composed of $>300$ Holstein lactating cows, used computerized animal records (health and production data), adopted systematic measures to control major contagious mastitis pathogens (Streptococcus agalactiae and Staphylococcus aureus), and were willing to comply with the study protocol.

Herds A and B were composed of 400 and 1700 lactating cows who produced an average of 35 and $41 \mathrm{~kg}$ of milk/day, with bulk tank milk SCC of 346,000 and 366,000 cells/mL, respectively. Cows of herd A were housed in a free-stall barn bedded with rubber mattresses and sawdust, and milked twice a day in a rotary parlor. Cows of herd B were housed in a cross-ventilated free-stall barn bedded with sand and milked 3 times a day in a rotary parlor. Both farms adopted mastitis control programs based on the NMC's 10-point mastitis control plan (National Mastitis Council) and used complete milking routines consisting of visual examination of foremilk, pre-dipping with chlorine (herd A) and iodine (herd B) solutions, drying of teats with individual cloth (herd A) and paper (herd B) towels, milking of cows followed by automatic cluster detachment, and use of post-dipping with iodine solutions.

Both farms used standardized treatment protocols for CM. Mild and moderate cases were treated primarily with 3-5 intramammary infusions of ceftiofur (Spectramast, Zoetis, NJ, USA) or cefquinome (Cobactan, MSD Animal Health, NJ, USA). Severe cases were treated with the protocols aforementioned, in addition to supportive and systemic antimicrobial therapy.

\subsection{Study design and data collection procedures}

We conducted a case-control study with incidence density sampling (Dohoo et al., 2010). Farms were initially visited to explain the study protocol and obtain informed consent. Milking technicians and herd managers were trained by study personnel for standardized detection of CM and collection of aseptic milk samples.

Farms were visited monthly for collection of data and frozen milk samples. Farm A was visited between July 2013 and April 2014, and Farm B was visited between June 2014 and March 2015. Clinical mastitis was detected at every milking by milking technicians, by visual examination of foremilk. Milking technicians were asked to collect aseptic milk samples $(15 \mathrm{~mL})$ from all cases of $\mathrm{CM}$ that occurred during the study, before administration of intramammary treatment, or at detection for cases that were not treated. Samples were frozen on the farms and collected monthly by study personnel. Cows were treated according to each farm's standardized protocol and information pertaining to each case (number of quarters affected and treatment protocol) was recorded. Production data, such as monthly dairy herd improvement association (DHI) milk production and SCC, parity, and days in milk (DIM) were obtained from the farms' management software.

\subsection{Definition and selection of cases and controls}

Clinical mastitis was defined as the presence of milk visual abnormalities (such as flakes, pus, and changes in color), which could be accompanied or not by alterations in the mammary gland (e.g., swelling, redness and pain) and in the systemic state of the cow (e.g., fever and dehydration).

Cows were eligible to be cases or controls if they were in lactation and included in the DHI monthly testing program. Cows were observed prospectively from the beginning of the study and a case cow was defined when she experienced the second case of $\mathrm{CM}$ within the same lactation, regardless of the quarter affected. Only cases that occurred after 14 days from a previous case were considered new (Bar et al., 2007; Hertl et al., 2014). For each case cow, 3 control cows matched by days in milk ( \pm 15 days) were randomly selected using PROC SURVEY SELECT (SAS Institute, Cary, NC, USA) from the cohort of cows who did not experience any case of CM.

A list including cases and controls was produced monthly, before each visit day, to identify cows for field measurements. Control cows were eligible to become cases if they experienced repeated cases of CM afterwards. Cows could have been selected as controls more than once during the study, as part of the random selection procedure (Dohoo et al., 2010).

\subsection{Field measurements}

On each visit day, a series of udder and teat characteristics were recorded during milking time. Investigators were masked to the casecontrol status of each animal. After milking of each selected animal, the following measurements were performed on udders and 2 contralateral teats (e.g., right front and left rear teats of a cow, and left front and right rear teats of the next cow): 1) teat-end hyperkeratosis scoring: 4- 
point scale ranging from $1=$ no ring, to 4 very rough ring (Mein et al., 2001); 2) milking ease scoring was performed 1 min after cluster automatic detachment, by milking 5 streams of milk by hand. A hand dynamometer (Camry, Zhongshan, China) with a precision of $0.1 \mathrm{kgF}$ was used to standardize the scores in a 3-point scale. Evaluators estimated the force needed to express milk from teats, where a score of $1=$ very easy to milk ( $\leq 1 \mathrm{kgF}$ ), 2 (between 1 and $2 \mathrm{kgF}$ ), and $3=$ difficult to milk ( $\geq 3 \mathrm{kgF}$ ). Evaluators used the dynamometer to develop a sense for the requisite forces associated with each score. Milking ease scoring was performed by 2 authors ( 1 per farm), who were both trained by the principal investigator. To avoid measurement bias, the same investigator scored all cases and controls of the same farm; 3) teat length and diameter (at mid barrel) were measured with a caliper (Mitutoyo, Sao Paulo, Brazil); 4) teat-to-ground distance; and 5) udder position in relation to the hock: defined as below, same line, or above, based on the position of the udder floor in relation to the point of the hock (calcaneous).

\subsection{Microbiological analyses}

Microbiological examination of milk was conducted in the UNESP' $\mathrm{s}$ Mastitis Research Laboratory, according to the NMC procedures (National Mastitis Council, ,1999). An aliquot of $10 \mu \mathrm{L}$ of milk was streaked onto blood and McConkey agar plates, which were incubated at $37^{\circ} \mathrm{C}$. Plates were examined at 24,48 , and $72 \mathrm{~h}$. Diagnosis of mastitis pathogens was performed based on morphology and biochemical reactions. Staphylococcus aureus was differentiated from other staphylococci by means of sugar fermentation (mannitol, maltose, and trehalose) and tube coagulase reactions. Streptococcus spp were diagnosed based on the CAMP test, esculin, bile-esculin, and sodium hypurate reactions. Gram-negative bacteria were diagnosed based on growth characteristics on McConkeky agar, such as lactose production and colony morphology, and reactions on motility-indole-ornithine, citrate, and triple sugar iron agar slants.

An intramammary infection was defined as growth of $>2$ colonies of the same type. Non-significant growth was defined when $<3$ colonies of the same type were present on plates and were considered negative for analysis. Samples were contaminated when $>2$ types of colonies grew on plates. Mixed intramammary infections were defined when there was significant growth ( $>2$ colonies of the same type) of 2 species.

\subsection{Sample size calculation}

The sample size was calculated based on the following assumptions: proportion of exposed cases (i.e., having milking ease score $=1$ or teatend hyperkeratosis score $\geq 3$ ) $=0.6$; proportion of exposed controls $=0.3$, and ratio of cases to controls $=1: 3$. The ratio of cases to controls (1:3) was used to increase the precision of the estimates (Dohoo et al., 2010). The prevalence of teat-end hyperkeratosis $\geq 3$ assumed for control cows (30\%) was based on a previous study conducted by 1 of the authors in similar herds (Bade et al., 2007). Based on these assumptions, 91 repeated cases and 271 controls would be needed to significantly detect an odds ratio of 2.0 (estimated effect for teat-end hyperkeratosis; Breen et al., 2009) with probability of a type I error $=0.05$ and power $=0.8$. Due to multivariable analyses and possible data losses, the attempted sample size was increased to 110 cases and 330 controls to achieve the proposed analytical goals. Sample size calculations were performed with OpenEpi (Open Source Epidemiologic Statistics for Public Health).

\subsection{Statistical analysis}

The study was designed to be analyzed at the cow level. Thus, for each cow, the mean of the field measurements recorded from rear and front teats (length and diameter, distance to ground, hyperkeratosis scoring, and milking ease scoring) was calculated and rounded to the nearest integer for analyses. Teat scores were analyzed as categorical variables.

Descriptive statistics were produced to characterize the study sample. The mean or the proportion of explanatory variables and epidemiologic characteristics (such as days to $\mathrm{CM}$ ) was compared between farms and between cases and controls using the Chi-square test (categorical variables) or ANOVA (continuous variables). The Wilcoxon Rank Sum test was used when variables were not normally distributed.

Logistic regression was then used to perform bivariate analysis and identify factors (continuous and categorical variables) individually associated with the occurrence of two successive cases of CM (yes or no). The Cochran-Mantel-Haenszel test was used to perform stratified analyses and identify possible confounding variables, such as parity and farm. Variables that were associated with the outcome at a significance level of 0.15 , as well as interactions between explanatory variables, were offered to a backward variable selection procedure to select a final multivariable model. A logistic regression model (PROC LOGISTIC; SAS Institute, Cary, NC, USA) was then constructed to estimate the odds of two successive cases of CM, as a function of the remaining explanatory variables.

Individual cow SCC from the DHI test prior to the second case of $\mathrm{CM}$ was strongly associated with the odds of two successive cases of $\mathrm{CM}$ $(\mathrm{P}<0.01$; Table 4); nonetheless, its inclusion in the multivariable model resulted in 95 missing values due to cows who had a second case of CM prior to the first DHI test in their lactation, or did not have SCC results for other reasons (such as fail to collect a milk sample). Except for parity, inclusion of SCC prior to the second case in the final model slightly changed $(<10 \%)$ the coefficients and the statistical significance of the other explanatory variables (i.e., was not a confounding factor; Dohoo et al., 2010). Parity was no longer significant after inclusion of SCC prior to the second case in the model, probably due to collinearity (parity was strongly associated with SCC prior to the second case; $\mathrm{P}<$ 0.01). Therefore, due to the large amount of missing data, we removed SCC prior to the second case of CM from the final model and only presented the unadjusted association (Table 4).

Although farm was not statistically significant, it was forced into the final model due its confounding effect (there was a change in $>10 \%$ in the coefficients of the other variables when farm was included in the model). Due to the sampling strategy utilized (incidence density sampling), the logistic model was not conditional and the odds ratio was expected to be a valid estimation of the incidence ratio (Dohoo et al., 2010).

\section{Results}

\subsection{Descriptive statistics}

A total of 113 case cows and 324 control cows (61 cases and 168 controls from farm A, and 52 cases and 156 controls from farm B) were included in the final dataset, resulting in a ratio of 2.9 controls for each case. Teat-to-ground distance could not be measured on 2 cows and milk production at the first DHI test was not available for 45 cows of farm A and 27 cows of farm B.

Although both herds were composed of Holstein cows, animals had different characteristics (Tables 1, 2). Cows of farm B had a greater proportion of teats with "very rough" $($ score $=4)$ teat ends, had shorter and wider teats, and on average produced more milk than cows of farm A $(\mathrm{P}<0.05$, Tables 1,2$)$. Cows of farm B also had a greater proportion of teats scored as "very easy to milk" (score $=1$ ) and udders positioned above the hock, as compared with cows of farm A $(\mathrm{P}<0.05$, Table 1$)$.

The distribution of treatments for the first of case of CM was: Farm A: intramammary ceftiofour for 5 days $(89.8 \%)$, intramammary ceftiofour for 8 days (8.1\%), and intramammary ceftiofour for 3 days (2.0\%); and Farm B: intramammary ceftiofour for 5 days $(63.1 \%)$, 
Table 1

Characteristics of the cows enrolled into the study, by farm (categorical variables).

\begin{tabular}{|c|c|c|c|c|c|}
\hline \multirow[t]{2}{*}{ Variable } & \multicolumn{2}{|c|}{ Farm A } & \multicolumn{2}{|c|}{ Farm B } & \multirow[t]{2}{*}{ P-value } \\
\hline & $\mathrm{N}$ & $\%$ & $\mathrm{~N}$ & $\%$ & \\
\hline Cow status ${ }^{\text {a }}$ & & & & & 0.70 \\
\hline Case & 61 & 26.6 & 52 & 25.0 & \\
\hline Control & 168 & 73.4 & 156 & 75.0 & \\
\hline Teat-end hyperkeratosis score & & & & & $<0.01$ \\
\hline 1 (no ring and no keratin) & 11 & 4.8 & 34 & 16.4 & \\
\hline 2 (ring with no keratin) & 109 & 47.6 & 75 & 36.2 & \\
\hline 3 (presence of keratin - rough) & 82 & 35.8 & 59 & 28.5 & \\
\hline 4 (presence of much keratin - very rough) & 27 & 11.8 & 39 & 18.8 & \\
\hline Udder position in relation to the hock & & & & & $<0.01$ \\
\hline Below & 57 & 24.9 & 12 & 5.8 & \\
\hline Above & 132 & 57.6 & 152 & 73.1 & \\
\hline Same line & 40 & 17.5 & 44 & 21.2 & \\
\hline Milking ease score ${ }^{\mathrm{b}}$ & & & & & 0.01 \\
\hline 1 (very easy to milk) & 59 & 25.8 & 69 & 33.3 & \\
\hline 2 (intermediary) & 129 & 56.3 & 120 & 58.0 & \\
\hline 3 (difficult to milk) & 41 & 17.9 & 18 & 8.7 & \\
\hline Parity & & & & & 0.26 \\
\hline 1 & 91 & 39.7 & 51 & 31.7 & \\
\hline 2 & 66 & 28.8 & 52 & 32.3 & \\
\hline$>2$ & 72 & 31.4 & 58 & 36.0 & \\
\hline
\end{tabular}

${ }^{a}$ A case cow was defined when she experienced the second case of clinical mastitis within the same lactation. For each case cow, 3 control cows matched by days in milk were randomly selected from the cohort of cows who did not experience any case of clinical mastitis.

${ }^{\mathrm{b}}$ Assessment of the patency of the teat canal according to a 3-point scale ranging from $1=$ very easy to milk to 3 =difficult to milk, based on the amount of force that needed to be applied to extract milk from the teat by hand. Milking ease scoring was performed 1 min after cluster automatic detachment, by milking 5 streams of milk by hand.

Table 2

Characteristics of the cows enrolled into the study, by farm (continuous variables).

\begin{tabular}{|c|c|c|c|c|c|c|c|c|}
\hline \multirow[t]{2}{*}{ Variable } & \multicolumn{4}{|c|}{ Farm A } & \multicolumn{4}{|c|}{ Farm B } \\
\hline & $\mathrm{N}$ & Mean $^{\mathrm{a}}$ & SD & Median $^{\mathrm{a} n}$ & $\mathrm{~N}$ & Mean & SD & Median \\
\hline $\begin{array}{l}\text { Teat length } \\
\text { (mm) }\end{array}$ & 229 & $56.3^{\mathrm{a}}$ & 9.5 & - & 208 & $46.9^{\mathrm{b}}$ & 8.7 & - \\
\hline $\begin{array}{l}\text { Teat diameter }{ }^{\mathrm{b}} \\
\quad(\mathrm{mm})\end{array}$ & 229 & $23.0^{\mathrm{a}}$ & 3.1 & - & 208 & $24.1^{\mathrm{b}}$ & 3.3 & - \\
\hline $\begin{array}{l}\text { Teat-to-ground } \\
\text { distance }(\mathrm{cm})\end{array}$ & 229 & $48.6^{\mathrm{a}}$ & 7.0 & - & 206 & $53.2^{\mathrm{b}}$ & 6.8 & - \\
\hline $\begin{array}{l}\text { Milk production } \\
\text { (first DHI } \\
\text { test }^{\mathrm{c}} \text { ) }\end{array}$ & 184 & $29.6^{\mathrm{a}}$ & 11.6 & - & 181 & $40.4^{\mathrm{b}}$ & 10.4 & - \\
\hline $\begin{array}{l}\text { Days in milk at } \\
\text { first case of } \\
\mathrm{CM}^{\mathrm{d}}\end{array}$ & 61 & - & - & $88.0^{\mathrm{a}}$ & 52 & - & - & $65.5^{\mathrm{a}}$ \\
\hline $\begin{array}{l}\text { Days in milk at } \\
\text { second case of } \\
\text { CM (days) }\end{array}$ & 61 & - & - & $154.0^{\mathrm{a}}$ & 52 & - & - & $119.5^{\mathrm{b}}$ \\
\hline $\begin{array}{l}\text { Interval between } \\
\text { cases (days) }\end{array}$ & 61 & - & - & $40.0^{\mathrm{a}}$ & 52 & - & - & $34.5^{\mathrm{a}}$ \\
\hline
\end{tabular}

${ }^{\text {a }}$ Different letters within the same row indicates statistically significant $(\mathrm{P}<0.05)$ differences between means or medians.

${ }^{\mathrm{b}}$ Measurements were performed on 2 contralateral teats (e.g., right front and left rear teats of a cow, and left front and right rear teats of the next cow) after milking of each selected animal. Results were reported as the mean of the 2 measurements.

${ }^{\mathrm{c}}$ Milk production on the first Dairy Herd Improvement test day of lactation.

${ }^{\mathrm{d}}$ Clinical mastitis.

intramammary cefquinome for 5 days (14.0\%), intramammary cefoperazone for 5 days (12.3\%), intramammary cephalexin for 5 days (5.3\%), and other intramammary treatments (5.3\%).

\subsection{Clinical mastitis epidemiology}

Of the case cows, the median time to occurrence of the first and
Table 3

Results of microbiological examination of milk for the first and second cases of clinical mastitis that occurred within the same lactation.

\begin{tabular}{|c|c|c|c|c|c|c|c|c|}
\hline \multirow[t]{3}{*}{ Diagnosis } & \multicolumn{4}{|c|}{ Farm A } & \multicolumn{4}{|c|}{ Farm B } \\
\hline & \multicolumn{2}{|c|}{ First case } & \multicolumn{2}{|c|}{ Second case } & \multicolumn{2}{|c|}{ First case } & \multicolumn{2}{|c|}{ Second case } \\
\hline & $\mathrm{N}$ & $\%$ & $\mathrm{~N}$ & $\%$ & $\mathrm{~N}$ & $\%$ & $\mathrm{~N}$ & $\%$ \\
\hline $\begin{array}{r}\text { Citrobacter } \\
\text { freundii }\end{array}$ & 0 & 0.0 & 1 & 1.6 & 0 & 0.0 & 0 & 0.0 \\
\hline $\begin{array}{l}\text { Corynebacterium } \\
\text { bovis }\end{array}$ & 1 & 1.6 & 3 & 4.9 & 2 & 3.8 & 0 & 0.0 \\
\hline $\begin{array}{r}\text { Enterobacter } \\
\text { aerogenes }\end{array}$ & 1 & 1.6 & 2 & 3.3 & 0 & 0.0 & 0 & 0.0 \\
\hline Enterococcus spp. & 3 & 4.9 & 3 & 4.9 & 2 & 3.8 & 1 & 1.9 \\
\hline Escherichia coli & 9 & 14.8 & 9 & 14.8 & 5 & 9.6 & 2 & 3.8 \\
\hline $\begin{array}{l}\text { Klebsiella } \\
\quad \text { pneumoniae }\end{array}$ & 2 & 3.3 & 1 & 1.6 & 4 & 7.7 & 3 & 5.8 \\
\hline Klebsiella oxytoca & 0 & 0.0 & 0 & 0.0 & 1 & 1.9 & 1 & 1.9 \\
\hline Yeast & 4 & 6.6 & 1 & 1.6 & 0 & 0.0 & 2 & 3.8 \\
\hline Pasteurella spp. & 1 & 1.6 & 0 & 0.0 & 0 & 0.0 & 1 & 1.9 \\
\hline Proteus spp. & 0 & 0.0 & 0 & 0.0 & 1 & 1.9 & 0 & 0.0 \\
\hline Prototheca spp. & 0 & 0.0 & 0 & 0.0 & 0 & 0.0 & 1 & 1.9 \\
\hline Pseudomonas spp. & 1 & 1.6 & 0 & 0.0 & 1 & 1.9 & 0 & 0.0 \\
\hline $\begin{array}{l}\text { Staphylococcus } \\
\text { aureus }\end{array}$ & 3 & 4.9 & 4 & 6.6 & 0 & 0.0 & 0 & 0.0 \\
\hline $\begin{array}{l}\text { Coagulase-negative } \\
\text { staphylococci }\end{array}$ & 4 & 6.6 & 2 & 3.3 & 5 & 9.6 & 8 & 15.4 \\
\hline $\begin{array}{l}\text { Streptococcus } \\
\text { agalactiae }\end{array}$ & 0 & 0.0 & 1 & 1.6 & 0 & 0.0 & 0 & 0.0 \\
\hline $\begin{array}{l}\text { Streptococcus } \\
\text { dysgalactiae }\end{array}$ & 17 & 27.9 & 9 & 14.8 & 8 & 15.4 & 8 & 15.4 \\
\hline Streptococcus spp. & 0 & 0.0 & 3 & 4.9 & 1 & 1.9 & 3 & 5.8 \\
\hline $\begin{array}{l}\text { Streptococcus } \\
\text { uberis }\end{array}$ & 3 & 4.9 & 3 & 4.9 & 5 & 9.6 & 2 & 3.8 \\
\hline $\begin{array}{l}\text { Non-identified } \\
\text { Gram-negative } \\
\text { rods }\end{array}$ & 0 & 0.0 & 0 & 0.0 & 0 & 0.0 & 1 & 1.9 \\
\hline Mixed infection $^{\mathrm{a}}$ & 0 & 0.0 & 2 & 3.3 & 1 & 1.9 & 2 & 3.8 \\
\hline No growth & 10 & 16.4 & 17 & 27.9 & 12 & 23.1 & 14 & 26.9 \\
\hline Contaminated $^{\mathrm{b}}$ & 2 & 3.3 & 0 & 0.0 & 4 & 7.7 & 3 & 5.8 \\
\hline Total & 61 & 100.0 & 61 & 100.0 & 52 & 100.0 & 52 & 100.0 \\
\hline
\end{tabular}

${ }^{\text {a }}$ Growth of $>2$ colonies of 2 different species on the same plate.

${ }^{\mathrm{b}}$ Growth of $>2$ species on the same plate.

second cases of CM was 84 and 138 DIM, respectively. The median interval between the first and second cases of CM was 39 days.

Of the $113 \mathrm{~s}$ cases of $\mathrm{CM}, 49.6 \%(\mathrm{~N}=55)$ occurred in the same mammary gland. Of these 55 cases, $29.1 \%(\mathrm{~N}=16)$ had the same milk culture result from both first and second cases. Of these 16 cases, the distribution of milk culture results was: Streptococcus dysgalactiae (31.3\%), Streptococcus uberis (18.8\%), no growth (18.8\%), coagulasenegative staphylococci (12.5\%), Enterococcus spp (6.25\%), Escherichia coli (6.25\%), and Staphylococcus aureus (6.25\%).

For both herds, most cases of CM were caused by environmental pathogens, such as environmental streptococci and coliforms (Table 3). A low proportion of $\mathrm{CM}$ caused by major contagious pathogens (Streptococcus agalactiae and Staphylococcus aureus) was observed on both herds during the study (Table 3). Streptococcus agalactiae was never isolated from herd B and was eradicated from herd A during the initial phase of the study.

\subsection{Investigation of risk factors for repeated cases of clinical mastitis}

Results of the bivariate analysis (logistic regression) indicated that teat-to-ground distance, teat-end hyperkeratosis, udder position in relation to the hock, milking ease, parity, and milk production at the first DHI test of lactation were individually associated $(\mathrm{P}<0.05)$ with the occurrence of two successive cases of CM. The score "very easy to milk" (score $=1$ ) was observed in $47 \%$ of the case cows, as compared to $23 \%$ of the controls (Table 4). The strength and direction of the 
Table 4

Descriptive statistics and comparison of categorical explanatory variables between cases and controls.

\begin{tabular}{|c|c|c|c|c|c|}
\hline \multirow[t]{2}{*}{ Variable } & \multicolumn{2}{|c|}{ Cases $^{\mathrm{a}}$} & \multicolumn{2}{|c|}{ Controls $^{\mathrm{a}}$} & \multirow[t]{2}{*}{ P-value ${ }^{b}$} \\
\hline & $\mathrm{N}$ & $\%$ & $\mathrm{~N}$ & $\%$ & \\
\hline Teat-end hyperkeratosis score & & & & & $<0.01$ \\
\hline 1 (no ring and keratin) & 4 & 3.5 & 41 & 12.7 & \\
\hline 2 (ring with no keratin) & 43 & 38.0 & 141 & 43.6 & \\
\hline 3 (presence of keratin - rough) & 37 & 32.7 & 104 & 32.2 & \\
\hline 4 (presence of much keratin - very rough) & 29 & 25.6 & 37 & 11.4 & \\
\hline Udder position in relation to the hock & & & & & $<0.01$ \\
\hline Below & 34 & 30.0 & 35 & 10.8 & \\
\hline Above & 49 & 43.3 & 235 & 72.5 & \\
\hline Same line & 30 & 26.5 & 54 & 16.6 & \\
\hline Milking ease score $^{c}$ & & & & & $<0.01$ \\
\hline 1 (very easy to milk) & 53 & 46.9 & 75 & 23.2 & \\
\hline 2 (intermediary) & 48 & 42.8 & 201 & 62.2 & \\
\hline 3 (difficult to milk) & 12 & 10.6 & 47 & 14.5 & \\
\hline Parity & & & & & $<0.01$ \\
\hline 1 & 21 & 18.5 & 121 & 43.6 & \\
\hline 2 & 37 & 32.7 & 81 & 29.2 & \\
\hline$>2$ & 55 & 48.6 & 75 & 27.0 & \\
\hline Somatic cell count prior to the second case & & & & & $<0.01$ \\
\hline$\geq 200,000$ cells $/ \mathrm{mL}$ & 65 & 67.7 & 53 & 21.5 & \\
\hline$<200,000$ cells $/ \mathrm{mL}$ & 31 & 32.3 & 193 & 78.5 & \\
\hline
\end{tabular}

a A case cow was defined when she experienced the second case of clinical mastitis within the same lactation. For each case cow, 3 control cows matched by days in milk were randomly selected from the cohort of cows who did not experience any case of clinical mastitis.

${ }^{\mathrm{b}} \mathrm{P}$-value resulting from the Chi-square test.

c Assessment of the patency of the teat canal according to a 3-point scale ranging from $1=$ very easy to milk to $3=$ difficult to milk, based on the amount of force that needed to be applied to extract milk from the teat by hand. Milking ease scoring was performed $1 \mathrm{~min}$ after cluster automatic detachment, by milking 5 streams of milk by hand.

association between milking ease and the occurrence of two successive cases of CM was consistent among all parity categories. The percentages of cases and controls scored as "very easy to milk" were $57.1 \%$ and $27.3 \%$ for cows of parity $=1,48.7 \%$ and $17.5 \%$ for cows of parity $=2$, and $41.8 \%$ and $21.3 \%$ for cows of parity $>2$, respectively.

The proportion of cows with "very rough" teat ends (score=4) was 2.2 times greater among cases (25.6\%), as compared to controls (11.4\%; Table 4). However, the association between teat-end hyperkeratosis and the occurrence of two successive cases of CM lost statistical significance when adjusted by parity. Thirty percent of the case cows had their udder positioned below the hock, as compared to $11 \%$ of the controls (Table 4). Case cows also produced, on average, $3.1 \mathrm{~kg}$ more milk than control cows on the first DHI test day of lactation (Table 5).

Of the explanatory variables studied, 3 remained in the final multivariable model (Table 6). The odds of two successive cases of CM were 3.7 times greater for cows who were "very easy to milk" (score $=1$ ), as compared with cows who were "difficult to milk" (score $=3$; $\mathrm{P}<0.01$ ). Cows who had their udders below the hock and those of parity $>2$ were $3.6(\mathrm{P}<0.01)$, and $2.5(\mathrm{P}=0.02)$ times more likely to experience two successive cases of $\mathrm{CM}$, as compared to cows whose udders were positioned above the hock, and cows of parity 1 , respectively.

\subsection{Associations between explanatory variables}

Milking ease was associated with teat-end hyperkeratosis and teat length. The prevalence of cows with severe hyperkeratosis $($ score $=4$ ) was $22.7 \%, 13.7 \%$, and $5.1 \%$ for cows scored as 1 (very easy to milk), 2 , and 3 (difficult to milk), respectively ( $\mathrm{P}<0.01$ for the parity-adjusted association - Cochran-Mantel-Haenszel Chi-Squared Test). Mean ( \pm SD) teat length was $48.4 \pm 9.7,52.8 \pm 9.9$, and $55.6 \pm 10.3 \mathrm{~mm}$ for cows whose milking ease score was 1,2 , and 3 , respectively $(\mathrm{P}<0.01$ for the parity-adjusted association - ANOVA). Parity $(\mathrm{P}=0.54)$ and milk
Table 5

Descriptive statistics and comparison of continuous explanatory variables between cases and controls.

\begin{tabular}{|c|c|c|c|c|}
\hline Variable & $\mathrm{N}$ & Mean & $\mathrm{SD}^{\mathrm{a}}$ & P-value ${ }^{b}$ \\
\hline Teat length $^{\mathrm{c}}(\mathrm{mm})$ & & & & 0.98 \\
\hline Case $^{\mathrm{d}}$ & 113 & 51.8 & 9.6 & \\
\hline Control $^{\mathrm{d}}$ & 324 & 51.8 & 10.4 & \\
\hline Teat diameter ${ }^{\mathrm{c}}(\mathrm{mm})$ & & & & 0.23 \\
\hline Case & 113 & 23.8 & 3.4 & \\
\hline Control & 324 & 23.4 & 3.2 & \\
\hline Teat-to-ground distance ${ }^{\mathrm{c}}(\mathrm{cm})$ & & & & $<0.01$ \\
\hline Case & 113 & 48.0 & 6.8 & \\
\hline Control & 322 & 51.7 & 7.3 & \\
\hline Milk production $^{\mathrm{e}}(\mathrm{kg})$ & & & & 0.03 \\
\hline Case & 97 & 37.2 & 13.8 & \\
\hline Control & 234 & 34.1 & 11.6 & \\
\hline
\end{tabular}

${ }^{\text {a }}$ Standard deviation.

b P-value resulting from ANOVA.

${ }^{\mathrm{c}}$ Measurements were performed on 2 contralateral teats (e.g., right front and left rear teats of a cow, and left front and right rear teats of the next cow) after milking of each selected animal. Results were reported as the mean of the 2 measurements.

d A case cow was defined when she experienced the second case of clinical mastitis within the same lactation. For each case cow, 3 control cows matched by days in milk were randomly selected from the cohort of cows who did not experience any case of clinical mastitis.

e Milk production on the first DHI test day of lactation.

Table 6

Multivariate investigation of risk factors for the occurrence of two successive cases of clinical mastitis within the same lactation.

\begin{tabular}{lllc}
\hline Variable & Odds ratio $^{\mathrm{a}}$ & $95 \% \mathrm{CI}^{\mathrm{b}}$ & P-value \\
\hline Farm & & & 0.19 \\
B & Reference & & \\
$\mathrm{A}$ & 0.7 & $0.4-1.2$ & \\
Parity & & & 0.02 \\
1 & Reference & & \\
2 & 2.4 & $1.3-4.7$ & \\
$>2$ & 2.5 & $1.2-5.1$ & $<0.01$ \\
Udder position in relation to the hock & & & \\
Above & Reference & & \\
Same line & 1.9 & $1.0-3.5$ & \\
Below & 3.6 & $1.7-7.5$ & \\
Milking ease score & & & \\
1 (difficult to milk) & Reference & & \\
2 (intermediary) & 1.1 & $0.5-2.5$ & \\
3 (very easy to milk) & 3.7 & $1.7-8.4$ & \\
\hline
\end{tabular}

a Odds ratio derived from a multivariable logistic regression model

${ }^{\mathrm{b}}$ Confidence interval

c Assessment of the patency of the teat canal according to a 3-point scale ranging from $1=$ very easy to milk to $3=$ difficult to milk, based on the amount of force that needed to be applied to extract milk from the teat by hand. Milking ease scoring was performed $1 \mathrm{~min}$ after cluster automatic detachment, by milking 5 streams of milk by hand.

production at the first $\mathrm{DHI}$ test $(\mathrm{P}=0.39)$ were not associated with milking ease.

Besides being associated with milking ease, teat-end hyperkeratosis was associated with parity and teat length. The prevalence of cows with severe hyperkeratosis (score $=4$ ) was $8.5 \%, 18.6 \%$, and $23.1 \%$ for cows of parity 1,2 , and $>2$, respectively $(\mathrm{P}<0.01$, Chi-square Test). Mean teat length was $45.9 \pm 9.2,51.1 \pm 10.3,53.9 \pm 10.3$, and $53.4 \pm 8.8 \mathrm{~mm}$ for cows whose teat-end hyperkeratosis score was 1, 2, 3 and 4, respectively ( $\mathrm{P}<0.01$ for the parity-adjusted association, ANOVA).

\section{Discussion}

Findings of the present study reveal novel information on the relevance of teat and udder factors as predictors for two successive cases of CM. One of the motivations for this study was to investigate the hypothesis that genetic selection for increasing milking speed has 
resulted in impairment of the teat canal's capacity to maintain a tight barrier against invasion of mastitis pathogens. Results of the present work demonstrate that, among all factors investigated, milking ease was the strongest predictor of two successive cases of CM. Although this study was observational, our results support the hypothesis of a causal association between milk ease and the occurrence of two successive cases of CM because the association was consistent across farms and not confounded by parity or milk production. Moreover, as opposed to traditional case-control studies, the use of incident cases of CM allowed the establishment of a well-defined temporal relationship between exposure (milking ease score $=1$ ) and outcome (two successive cases of CM) (Dohoo et al., 2010). It is not likely that the teat and udder physical characteristics studied changed during the time interval between detection of $\mathrm{CM}$ and the visit day on which measurements were performed.

In agreement with our findings, results of 2 previous studies support the theory that milking ease is associated with the capacity of the teat canal to maintain a physical barrier that prevents pathogens from entering the mammary gland. Weiss et al. (2004) demonstrated that the length of the teat canal was negatively associated with milk flow rate, suggesting that selection for increasing milk flow rate can result in teats with shorter teat canals. Grindal and Hillerton (1991) reported that the incidence of mastitis was 12 times greater for cows whose peak flow rate was greater than $1.6 \mathrm{~kg} /$ minute, as compared with cows whose peak flow rate was less than $0.8 \mathrm{~kg} /$ minute. Slettbakk et al. (1995) also conducted a case-control study and reported that milk flow rate was positively but marginally associated with the occurrence of CM.

In contrast, results of genetic studies are inconsistent (Rupp and Boichard, 2003) and indicate a lack of genetic correlation (Rupp and Boichard, 1999), or even a negative correlation (Lund et al., 1994) between milking ease and the occurrence of CM. It is important to note that, in those studies, milking ease scoring was performed by dairy farmers using a subjective ordinal scale, based on a combination of milking speed and the cows' temperament during milking (Lund et al., 1994; Rupp and Boichard, 1999). To our knowledge, assessment of the patency of the teat canal by physical examination has not been performed in genetic studies including large populations of animals.

One limitation of this study was the lack of milk flow rate data, as measured by electronic sensors at milking time. Although milking ease scoring was performed to assess the patency of the teat canal and possibly estimate milk flow rate, sensor data would have been important to validate this assumption. The linear association found between milking ease and teat length (cows with longer teats were more difficult to milk) disagrees with the findings reported by Weiss et al. (2004), who suggested that teat length was not associated with milk flow rate. Therefore, it is possible that the milking ease scoring system used here is not greatly correlated with milk flow rate during milking. Milk flow rate has been associated with several other factors, such as milk production, pre-milking stimulation and udder filling (Bruckmaier and Hilger, 2001; Tancin et al., 2006; Sandrucci et al., 2007), length of the teat canal (Weiss et al., 2004), and other factors associated with milk production (e.g., parity, stage of lactation, and quarter position).

Regardless of its association with milk flow rate, results of this study suggest that assessment of the teat canal's patency by means of physical examination can be justified. Due to the negative impact of successive cases of $\mathrm{CM}$ on dairy production, further investigations are needed to elucidate the role of the teat canal in preventing mastitis for modern cows that have been selected for increased milk production, shorter teats, and greater milk flow rates.

In addition to milking ease, the effect of teat-end hyperkeratosis on the risk of a repeated case of $\mathrm{CM}$ was of interest because previous studies reported conflicting results. Some authors (Neijenhuis et al., 2001; Bhutto et al., 2010) reported well-defined positive associations between teat-end hyperkeratosis and occurrence of mastitis, whereas other authors reported that only severe hyperkeratosis was associated with mastitis (Zadoks et al., 2001; Breen et al., 2009), or that there was no association whatsoever (Asadpour et al., 2015; Zoche-Golob et al., 2015).

The prevalence of teat-end hyperkeratosis was high on the farms studied, which favored the investigation of its association with CM. Even so, the association was only significant in the bivariate analysis and lost its significance when adjusted by parity and milking ease. The association between teat-end hyperkeratosis and the occurrence of two successive cases of CM was confounded by parity. Teat-end hyperkeratosis was also associated with milking ease, suggesting that severe hyperkeratosis leads to disruption of the teat canal's physical integrity and increased susceptibility to CM. Results of this study suggest that the effect of hyperkeratosis on the occurrence of two successive cases of $\mathrm{CM}$ is not as relevant as the effect of other factors studied, such as milking ease, parity, and udder position in relation to the hock.

Udder position in relation to the hock remained in the final multivariable model and indicated that cows with deep udders are at greater risk of experiencing two successive cases of CM. This finding agrees with previous works conducted to identify udder physical characteristics associated with the occurrence of CM (Slettbakk et al., 1995; Ruepp and Boichard, 1999). Likewise, results of this study agree with a body of research that has demonstrated that parity and milk production are risk factors for single and repeated episodes of CM (Bar et al., 2007; Pinzón-Sánchez and Ruegg, 2011; Hertl et al., 2014).

While there is not a scientifically validated time interval used to define a new case of CM (after a previous case), the interval used here (14 days) has been used in several previous studies (Bar et al., 2007; Hertl et al., 2014). Using shorter intervals can increase the probability of including relapses in the analysis (i.e., cases that fail to cure and would therefore be considered new). The DIM to occurrence of the first (84 DIM) and second (138 DIM) cases of CM were similar to those reported in a previous study including 5 large herds in the United States (91 and 140 DIM, respectively; Bar et al., 2007). Likewise, the distribution of pathogens causing CM was mostly comprised of environmental organisms (coliforms and environmental streptococci) and was similar to those reported in recent North American studies (Lago et al., 2011; Oliveira and Ruegg, 2014).

Enrolling farms characterized by this pathogen profile was important to study associations between cow physical characteristics and the risk of CM because persistent IMI due to contagious pathogens (such as Staphylococcus aureus) increases the risk of successive cases of CM caused by the same pathogen (Cha et al., 2016). Even though half of the second cases occurred in the same mammary gland, only $29.1 \%$ of these cases had the same microbiological result for both cases. In agreement with these findings, Abureema et al. (2014) reported that even when the same species (Streptococcus uberis) was isolated from recurrent cases of $\mathrm{CM}$, molecular analyses indicated that $74 \%$ were caused by different strains. These findings highlight the importance of cow factors for the occurrence of repeated cases of $\mathrm{CM}$ on modern dairies that have successfully controlled contagious mastitis pathogens. The authors believe that results of this study can be extrapolated to other herds with similar characteristics worldwide.

\section{Conclusions}

Results of the present study provide novel information on teat and udder characteristics that can be risk factors for two successive cases of CM. Cows who were scored as "very easy to milk", had their udders below the hock, and were of parity $>2$ were more likely to experience two successive cases of CM, as compared with cows who were "difficult to milk", had their udders positioned above the hock, and were of parity 1 , respectively. Teat-end hyperkeratosis was moderately associated with the occurrence of two successive cases of $\mathrm{CM}$ and this association was confounded by parity and milking ease, suggesting a shared but moderate effect. 
Although half of the second cases occurred in the same mammary gland, only $29.1 \%$ had the same microbiological result for both cases, suggesting that udder and teat physical factors are important predictors of successive cases of CM on farms that have successfully controlled contagious mastitis pathogens. Findings of this study encourage further investigation to elucidate the role of the teat canal in preventing mastitis for modern cows that have been selected for increased milk production, shorter teats, and greater milk flow rates.

\section{Conflict of interest statement}

The authors state that there were no conflicts of interest that could have influenced the results of this work.

\section{Acknowledgement}

The authors thank the dairy farmers and their staff for collaborating with this study. We also thank Natalia M. Sobreira, Sergio Soriano, and Tarsila Franckin for collaborating with the study. The Sao Paulo Research Foundation (FAPESP) funded this research project (grant 2013/03482-6) and the scholarships of Arthur Pombo Almeida (2014/ 12642-0) and Bruna dos Santos (2013/02569-0).

\section{References}

Abureema, S., Smooker, P., Malmo, J., Deighton, M., 2014. Molecular epidemiology of recurrent clinical mastitis due to Streptococcus uberis. J. Dairy Sci. 97, 285-290.

Asadpour, R., Bagherniaee, H., Houshmandzad, M., Fatehi, H., Rafat, A., Nofouzi, K., Maftouni, K., 2015. Relationship between teat end hyperkeratosis with intra mammary infection and somatic cell counts in lactating dairy cattle. Rev. Méd. Vét. 166, 266-270.

Bade, R.D., Hohmann, K.J., Pantoja, J., Zucali, M., Ruegg, P., Reinemann, D.J., 2007. Evaluating milking performance in Wisconsin and Italy. In: Proceedings of the International Symposium on Advances in Milking, Teagasc, Moorepark Dairy Production Research Centre, Fermoy, Ireland.

Bar, D., Gröhn, Y.T., Bennett, G., González, R.N., Hertl, J.A., Schulte, H.F., Tauer, L.W., Welcome, F.L., Schukken, Y.H., 2007. Effect of repeated episodes of generic clinical mastitis on milk yield in dairy cows. J. Dairy Sci. 90, 4643-4653.

Bar, D., Gröhn, Y.T., Bennett, G., González, R.N., Hertl, J.A., Schulte, H.F., Tauer, L.W., Welcome, F.L., Schukken, Y.H., 2008. Effects of repeated episodes of generic clinical mastitis on mortality and culling in dairy cows. J. Dairy Sci. 91, 2196-2204.

Barkema, H.W., Schukken, Y.H., Lam, T.J.G.M., Beiboer, M.L., Benedictus, G., Brand, A., 1999. Management practices associated with the incidence rate of clinical mastitis. J. Dairy Sci. 82, 1643-1654.

Barnouin, J., Bord, S., Bazin, S., Chassagne, M., 2005. Dairy management practices associated with incidence rate of clinical mastitis in low somatic cell score herds in France. J. Dairy Sci. 88, 3700-3709.

Bradley, A.J., Leach, K.A., Breen, J.E., Green, L.E., Green, M.J., 2007. Survey of the incidence and aetiology of mastitis on dairy farms in England and Wales. Vet. Rec. $160,253-258$.

Bradley, A.J., Green, M.J., 2001. Adaptation of Escherichia coli to the Bovine Mammary Gland. J. Clin. Microbiol. 39, 1845-1849.

Breen, J.E., Green, M.J., Bradley, A.J., 2009. Quarter and cow risk factors associated with the occurrence of clinical mastitis in dairy cows in the United Kingdom. J. Dairy Sci. 92, 2551-2561.

Bruckmaier, R.M., Hilger, M., 2001. Milk ejection in dairy cows at different degrees of udder filling. J. Dairy Res. 68, 369-376.

Bhutto, A.L., Murray, R.D., Woldehiwet, Z., 2010. Udder shape and teat-end lesions as potential risk factors for high somatic cell counts and intra-mammary infections in dairy cows. Vet. J. 183, 63-67.

Cha, E., Hertl, J.A., Schukken, Y.H., Welcome, F.L., Gröhn, Y.T., 2016. Evidence of no protection for a recurrent case of pathogen specific clinical mastitis from a previous case. J. Dairy Res. 83, 72-80.
Dohoo, I.R., Martin, W., Stryhn, H.E., 2010. Veterinary Epidemiologic Research second ed.. VER Inc., Charlottetown, Prince Edward Island, Canada.

Green, M.J., Burton, P.R., Green, L.E., Schukken, Y.H., Bradley, A.J., Peeler, E.J., Medley, G.F., 2004. The use of Markov chain Monte Carlo for analysis of correlated binary data: patterns of somatic cells in milk and the risk of clinical mastitis in dairy cows. Prev. Vet. Med. 64, 157-174.

Grindal, R.J., Hillerton, J.E., 1991. Influence of milk flow rate on new intramammary infection in dairy cows. J. Dairy Res. 58, 263-268.

Halasa, T., Huijps, K., Østerås, O., Hogeveen, H., 2007. Economic effects of bovine mastitis and mastitis management: a review. Vet. Q. 29, 18-31.

Hertl, J.A., Schukken, Y.H., Welcome, F.L., Tauer, L.W., Gröhn, Y.T., 2014. Pathogenspecific effects on milk yield in repeated clinical mastitis episodes in Holstein dairy cows. J. Dairy Sci. 97, 1465-1480.

Hillerton, J.E., Kliem, K.E., 2002. Effective treatment of Streptococcus uberis clinical mastitis to Minimize the Use of Antibiotics. J. Dairy Sci. 85, 1009-1014.

Huijps, K., Lam, T., Hogeveen, H., 2008. Costs of mastitis: facts and perception. J. Dairy Res 75, 113-120.

Lago, A., Godden, S.M., Bey, R., Ruegg, P.L., Leslie, K., 2011. The selective treatment of clinical mastitis based on-farm culture results: I. Effects on antibiotic use, milk withholding time, and short-term clinical and bacteriological outcomes. J. Dairy Sci. $94,4441-4456$.

Lund, T., Miglior, F., Dekkers, J.C.M., Burnside, E.B., 1994. Genetic relationships between clinical mastitis, somatic cell count, and udder conformation in Danish Holsteins. Livest. Prod. Sci. 39, 243-255.

Mein, G.A., Neijenhuis, F., Morgan, W.F., Reinemann, D.J., Hillerton, J.E., Baines, J.R. Ohnstad, I., Rasmussen, M.D., Timms, L., Britt, J.S., Farnsworth, R., Cook, N., Hemling, T., 2001. Evaluation of bovine teat condition in commercial dairy herds: 1 Non-infectious factors. In: Proceedings of the AABB-NMC International Symposium on Mastitis and Milk Quality, Vancouver, British Columbia, Canada, pp. 347-351.

Neijenhuis, F., Barkema, H.W., Hogeveen, H., Noordhuizen, J.P.T.M., 2001. Relationship between teat-end callosity and occurrence of clinical mastitis. J. Dairy Sci. 84, 2664-2672.

National Mastitis Council, 1999. Laboratory Handbook on Bovine Mastitis. National Mastitis Council Inc., Madison, Wisconsin, USA.

National Mastitis Council. Recommended Mastitis Control Program. 〈http://www. nmconline.org/docs/NMCchecklistInt.pdf (accessed 07.01.15.).

Olde Riekerink, R.G.M., Barkema, H.W., Kelton, D.F., Scholl, D.T., 2008. Incidence rate of clinical mastitis on Canadian dairy farms. J. Dairy Sci. 91, 1366-1377.

Oliveira, L., Ruegg, P.L., 2014. Treatments of clinical mastitis occurring in cows on 51 large dairy herds in Wisconsin. J. Dairy Sci. 97, 5426-5436.

Open Source Epidemiologic Statistics for Public Health. 〈http://www.OpenEpi.com) (accessed 02.10.13.).

Pantoja, J.C.F., Hulland, C., Ruegg, P.L., 2009. Somatic cell count status across the dry period as a risk factor for the development of clinical mastitis in the subsequent lactation. J. Dairy Sci. 92, 139-148.

Pinzón-Sánchez, C., Ruegg, P.L., 2011. Risk factors associated with short-term posttreatment outcomes of clinical mastitis. J. Dairy Sci. 94, 3397-3410.

Rupp, R., Boichard, D., 1999. Genetic parameters for clinical mastitis, somatic cell score, production, udder type traits, and milking ease in first lactation Holsteins. J. Dairy Sci. 82, 2198-2204.

Rupp, R., Boichard, D., 2003. Genetics of resistance to mastitis in dairy cattle. Vet. Res. $34,671-688$.

Sandrucci, A., Tamburini, A., Bava, L., Zucali, M., 2007. Factors affecting milk flow traits in dairy cows: results of a field study. J. Dairy Sci. 90, 1159-1167.

Slettbakk, T., Jorstad, A., Farver, T.B., Holmes, J.C., 1995. Impact of milking characteristics and morphology of udder and teats on clinical mastitis in first- and second-lactation Norwegian cattle. Prev. Vet. Med. 24, 235-244.

Steeneveld, W., Hogeveen, H., Barkema, H.W., van den Broek, J., Huirne, R.B.M., 2008. The influence of cow factors on the incidence of clinical mastitis in dairy cows. J. Dairy Sci. 91, 1391-1402.

Tancin, V., Ipema, B., Hogewerf, P., Macuhova, J., 2006. Sources of variation in milk flow characteristics at udder and quarter levels. J. Dairy Sci. 89, 978-988.

Weiss, D., Weinfurtner, M., Bruckmaier, R.M., 2004. Teat anatomy and its relationship with quarter and udder milk flow characteristics in dairy cows. J. Dairy Sci. 87, 3280-3289.

Zadoks, R.N., Allore, H.G., Barkema, H.W., Sampimon, O.C., Wellenberg, G.J., Gröhn, Y.T., Schukkent, Y.H., 2001. Cow- and quarter-level risk factors for Streptococcus uberis and Staphylococcus aureus mastitis. J. Dairy Sci. 84, 2649-2663.

Zoche-Golob, V., Haverkamp, H., Paduch, J.H., Klocke, D., Zinke, C., Hoedemaker, M., Heuwieser, W., Krömker, V., 2015. Longitudinal study of the effects of teat condition on the risk of new intramammary infections in dairy cows. J. Dairy Sci. 98, 910-917. 